150

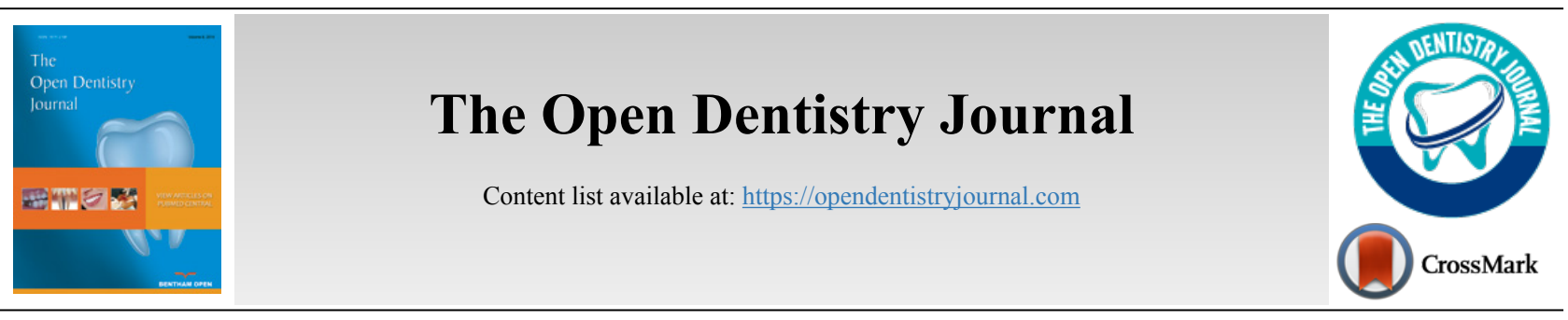

SYSTEMATIC REVIEW

\title{
Assessment of Peri-implant Buccal Bone Thickness Using Digital Imaging Techniques: A Systematic Review and Meta-analysis
}

\author{
Lauren Bohner ${ }^{1,2, *}$, Marcel Hanisch ${ }^{2}$, Israel Chilvarquer ${ }^{3}$, Johannes Kleinheinz $^{2}$ and Pedro Tortamano \\ ${ }^{I}$ Department of Prosthodontics, School of Dentistry, University of São Paulo, São Paulo, SP, Brazil \\ ${ }^{2}$ Department of Craniomaxillofacial Surgery, Hospital University Münster, Germany \\ ${ }^{3}$ Department of Stomatology, School of Dentistry, University of São Paulo, São Paulo, SP, Brazil
}

\begin{abstract}
:
Objectives:

This systematic review aimed to answer the following focused question: Do the currently available imaging techniques provide accuracy in the assessment of peri-implant buccal bone thickness?

Methods:

A search strategy was conducted in eight electronic databases, followed by an additional manual search in grey literature and references of selected articles. Studies evaluating the accuracy of imaging techniques to measure peri-implant buccal bone thickness were included. Individual risk of bias was assessed by the Quality Assessment Tool for Diagnostic Accuracy Studies-2 (QUADAS-2). Meta-analysis was performed to evaluate CBCT accuracy. The overall effect size was determined by means of the Z-test. Q test was used to evaluate the homogeneity of effect sizes among studies and $\mathrm{I}^{2}$ was applied to determine the variance within studies.

Results:

After an initial screening, 83 studies were further selected for full reading and 13 of them were considered eligible for this review. In sum, the accuracy of Cone-beam Computed Tomography (CBCT), of ultrasound, and of computed tomography were assessed. There was no statistically significant difference between $\mathrm{CBCT}$ and the gold standard $(\mathrm{p}=0.81)$. The mean difference between measurements of bone thickness obtained by CBCT and the goldstandard was $-0.0 .3 \mathrm{~mm}[95 \% \mathrm{CI}-0.29 ; 0.253 \mathrm{~mm}]$.

Conclusion:

CBCT showed acceptable accuracy for assessing peri-implant bone. No meaningful conclusion could be drawn about other techniques.
\end{abstract}

Keywords: Dental implants, diagnostic imaging, cone-beam computed tomography, diagnostic x-ray, ultrasonic imaging.

\begin{tabular}{|l|l|l|l|}
\hline Article History & Received: January 06, 2020 & Revised: February 27, 2020 & Accepted: March 08, 2020
\end{tabular}

\section{INTRODUCTION}

As far as the long-term outcome of dental implants is concerned, the health of soft and hard peri-implant tissues is essential to ensure a successful result $[1,2]$. In this sense, one of the main factors responsible for their integrity is the bone volume surrounding dental implants [3 - 8]. A thin buccal bone is known to be a risk factor for the long-term stability of periimplant tissues and may jeopardize esthetic and biological out-

\footnotetext{
* Address correspondence to this author at the Department of Prosthodontics, School of Dentistry, University of São Paulo, Av. Prof. Lineu Prestes, 2227, 05508-000 São Paulo, SP, Brazil; Tel: +55 113091 7885, Fax: +55 113091 7640; E-mail: lauren@usp.br
}

comes [9 - 11].Thus, assessment of buccal bone thickness during maintenance consultations is essential to prevent complications [1, 12].

Recently, Cone-beam Computed Tomography (CBCT) has allowed the non-invasive assessment of buccal bone thickness after implant placement [9, 13] Despite the well-validated reliability of $\mathrm{CBCT}$, limitations regarding image quality have been shown as a result of artifacts associated with dental implants [14]. Hence, especially in cases in which bone is thinner than $1 \mathrm{~mm}$, this may not be accurately detectable in tomographic images [15]. An additional aspect to consider is the ionizing radiation-induced by $\mathrm{CBCT}[16]$ which prevents its use for periodical monitoring of dental implants [17]. 
In this regard, novel digital modalities focusing on periimplant bone assessment have been evaluated to overcome these limitations [18 - 20]. Despite the promising results, the accuracy of new tridimensional techniques has not yet been validated in the literature. Previous systematic reviews have addressed the use of digital technologies for pre- and postoperative assessment of dental implants [17, 21, 22].Their accuracy in measuring peri-implant buccal bone thickness, however, has not yet been determined.

Considering that limiting factors can hamper the accuracy of CBCT, and that efforts have been made to find new techniques for measuring peri-implant bone thickness, the present study aimed to answer the following focused question: do the currently available tridimensional imaging techniques provide enough accuracy to assess peri-implant buccal bone thickness?

\section{METHODS}

\subsection{Protocol and Registration}

This systematic review was reported according to recommendations of "The Preferred Reporting Items for Systematic Reviews and Meta-Analyses"(PRISMA [23] and it is registered at PROSPERO under the reference number CRD42016044049.

\subsection{Eligibility Criteria}

PICO $(\mathrm{P}=$ patients; $\mathrm{I}=$ intervention; $\mathrm{C}=$ comparison; $\mathrm{O}=$ outcome) was defined as: tridimensional digital images of periimplant bone $(\mathrm{P})$, in which buccal bone thickness was measured (I) and compared with a physical or histological gold standard (C) in order to determine the accuracy $(\mathrm{O})$ of the imaging device.Accuracy was determined as the measurement error between the evaluated technique and a gold standard. In turn, this was defined as direct or histological measurements of peri-implant bone thickness.

Inclusion criteria comprised studies evaluating the accuracy of tridimensional imaging techniques to assess periimplant buccal bone thickness. No restriction on time or language was applied. The following parameters were considered as the exclusion criteria: 1) Case reports, literature reviews, letters or abstracts; 2) Assessment of further bone parameters other than buccal bone thickness; 3) Assessment of diagnostic methods not considered reliable for clinical use.

\subsection{Information Sources}

A main search strategy was developed according to PICO as following:

((((c“Dental Implants”[Mesh]) OR”Dental Implants, Single-Tooth"[Mesh] OR "Dental Implantation" OR "Dental Implant")) AND ("Bone-Implant Interface"[Mesh] OR bone OR "peri-implant bone" OR "buccal bone" OR "cortical bone"OR "bone dimension" OR "bone thickness")) AND ("Tomography, X-Ray Computed"[Mesh] OR "Tomography"[Mesh] OR "Spiral Cone-Beam Computed Tomography”[Mesh] OR “Ultrasonography”[Mesh] OR "Radiography, Dental"[Mesh] OR ultrasound OR "magnetic resonance" OR "CBCT" OR "digital volume tomography" OR "MRT” OR “Tridimensional Image")) AND ((“dimensional measurement accuracy" OR accuracy)).

This search wasapplied in PubMed (Medline)databases and used as a reference for the additional Science Direct, Scopus, Embase and $\mathrm{Web}$ of Science databases. In addition, gray literature was explored in ProQuest, Scholar Google and OpenGrey sources. All searches were conducted from July until November 2019, and updated in February 2020. The authors did not contact study authors to identify additional studies. A reference manager software (EndNote Web, Thomson Reuters) was used to organize references and remove duplicates.

\subsection{Study selection and Data collection process}

Study selection was performed in duplicate by two independent reviewers. First, studies were screened according to titles and abstracts. Those studies that met the inclusion criteria were selected for full-text reading. Based on the inclusion and exclusion criteria defined, articles considered eligible for this review were selected. When sufficient data were provided, studies presenting a similar methodology were includedin the quantitative analysis. In case of disagreement between two reviewers, a third reviewer was consulted to achieve a decision.

Data were extracted from the included articles by the first reviewer and checked by the second reviewer.

\subsection{Data Items}

The following data were considered of interest to answer the focused question: study data (author, year and country), sample features (sample size and type) and assessment (imaging technique, exposure parameters, bone thickness definition, gold standard), and measurement details (points of evaluation, number of examiners and repeatability), findings and conclusion.

\subsection{Risk of Bias in Individual Studies}

The methodological risk of bias assessment was carried out using the "Quality Assessment Tool for Diagnostic Accuracy Studies-2" (QUADAS-2) [24]. The validated tool consisted of checking questions related to the study design regarding four domains: "patient selection", "index test", "reference standard", and "flow and timing". The risk of bias is determined by checking each question as "yes", "no" or "unclear". The final result categorized the risk of bias as "high", "low" or "unclear" [24]. Review Manager 5.3 software (RevMan 5.3, The Nordic Cochrane Centre, Copenhagen, Denmark) was used to perform the quality assessment.

\subsection{Summary of Measures}

Continuous data (mean and standard deviation) were extracted from studies reporting the bone thickness measured by an imaging technique and by the gold standard.The difference in means was used for statistical analysis.In cases in which the study described the accuracy of different imaging devices, these were described separately. 


\subsection{Synthesis of Results}

Meta-analysis was performed with studies comparing CBCT with the physical measurements using the same software reported above (RevMan 5.3). A random-effect model was assumed. Averaging was weighted by inverse variance and standardized mean difference was defined as effect size. The overall effect size was determined by means of the Z-test, and $Q$ test was used to evaluate the homogeneity of effect sizes among studies. Heterogeneity within studies was evaluated by using inconsistency indexes $\left(\mathrm{I}^{2}\right) . \mathrm{I}^{2}$ greater than $50 \%$ was considered an indicator of substantial heterogeneity between studies $(\mathrm{p} \leq 0.05)[25]$.

\subsection{Risk of Bias Across Studies}

The small number of included studies did not support any further assessment of bias across studies.

\section{RESULTS}

\subsection{Study Selection}

A flow chart describing the selection process is shown in Fig. (1). The initial search resulted in 1106 studies. Subsequently, 357 duplicated articles were removed and 740 studies remained. After reading titles and abstracts, 70 articles were selected for a complete reading. Furthermore, nine out of 524 articles extracted from grey literature, in addition to four papers selected from manual search, were chosen for a more detailed evaluation. Thus, out of the total of 83 studies selected for full-reading analysis, 70 were excluded and 13 studies were considered eligible for this review. The list of excluded articles and their respective reasons for exclusion are listed in Appendix 1.

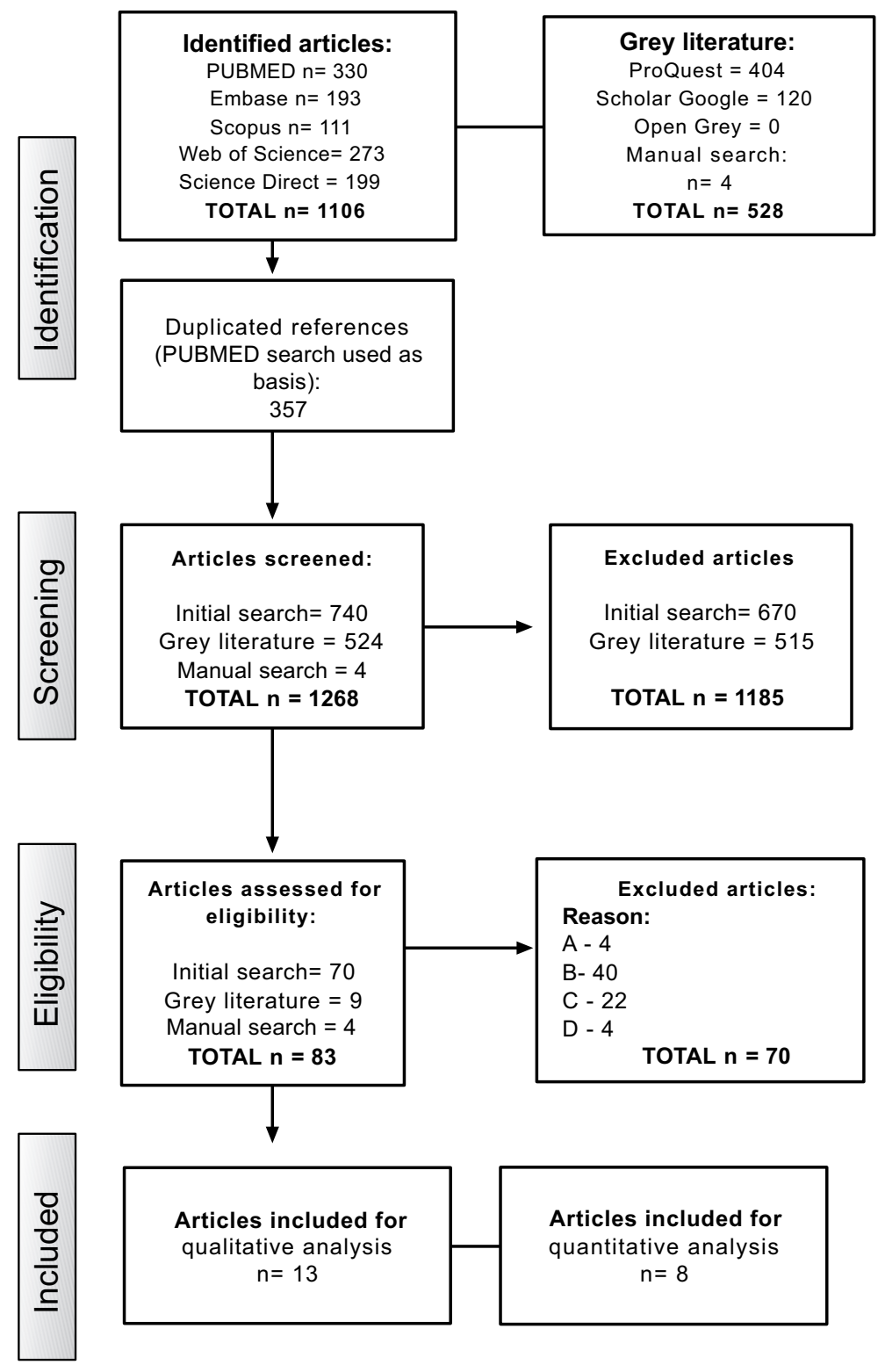

Fig. (1). Flowchart of search strategy. 


\subsection{Study Characteristics}

A summary of study characteristics is described in Tables $\mathbf{1}$ and 2. Accuracy of CBCT was assessed by all studies. Additionally, one study evaluated computed tomography (CT) [26] and 4 studies evaluated the use of ultrasound-based techniques (US) [27 - 30].

All included studies selected in this review were laboratory studies, in which a total of 219 implants were placed in cadaver jaws [28 - 31] dry skulls [29, 32, 33], porcine or bovine bone $[27,26,30,34-36]$ or dogs [12].

As a reference standard, one study used histological samples, [12] five studies used light microscopy [27, 29, 32 -
$34]$ and 2 studies performed physical measurements using a caliper [26, 28]. Digital images, used as a pre-operative scan without implants [31, 35, 37], optical scanner [30]or digital photograph [36] were also used as a reference.

\subsection{Risk of Bias within Studies}

Fig. (2) shows the QUADAS-2 assessment. In general, all studies presented a low risk of bias and few concerns about applicability. The patient selection domain was considered poor, since these were laboratory studies and a randomization process was not possible. For the same reason, the QUADAS-2 question "was a case-control avoided?" was considered not applicable to these studies.

Table 1. Summary of descriptive characteristics of included articles. CBCT $=$ cone beam computed tomography; CT= computed tomography; US= ultrasound.

\begin{tabular}{|c|c|c|c|c|c|c|c|c|}
\hline \multicolumn{2}{|l|}{ Study } & \multicolumn{2}{|c|}{ Sample } & \multirow{2}{*}{\begin{tabular}{|c|}
- \\
$\begin{array}{c}\text { Implants } \\
\text { (n) }\end{array}$
\end{tabular}} & \multirow{2}{*}{$\begin{array}{c}- \\
\text { Implant Dimension } \\
\text { (diameter x height) }\end{array}$} & \multicolumn{3}{|c|}{ Bone Assessment } \\
\hline Author Year & Country & \begin{tabular}{|c|} 
Bone \\
Sample \\
(n)
\end{tabular} & Type & & & $\begin{array}{l}\text { Imaging } \\
\text { Technique }\end{array}$ & $\begin{array}{l}\text { Exposure } \\
\text { Parameters }\end{array}$ & Gold Standard \\
\hline Bohner et al., 2017 & Brazil & 6 & Dry skulls & 18 & $3.75 \times 9 \mathrm{~mm}$ & $\begin{array}{c}\text { CBCT } \\
\text { (1:Carestream } \\
\text { 9300; 2: R100 } \\
\text { Veraview) }\end{array}$ & $\begin{array}{c}1: 70 \mathrm{kV}, 6.3 \mathrm{~mA} \\
8.03 \mathrm{~s}, 0.18 \mathrm{~mm} \text { voxel } \\
\text { size } 2: 75 \mathrm{kV}, 5 \mathrm{~mA}, \\
9.40 \mathrm{~s}, 125 \mu \mathrm{m} \text { voxel } \\
\text { size } \\
\end{array}$ & $\begin{array}{c}\text { Direct } \\
\text { measurements } \\
\text { (microscope) }\end{array}$ \\
\hline Bohner et al., 2019 & Brazil & 3 & Dry skulls & 10 & $3.75 \times 9 \mathrm{~mm}$ & $\begin{array}{c}\text { CBCT } \\
\text { (1:Carestream } \\
\text { 9300), US }\end{array}$ & \begin{tabular}{|c|} 
CBCT: $70 \mathrm{kV}, 6.3 \mathrm{~mA}$, \\
$8.03 \mathrm{~s}, 180 \mu \mathrm{m}$ voxel \\
size; US: $28 \mathrm{MHz}$ \\
bandwidth $84 \%$
\end{tabular} & $\begin{array}{c}\text { Direct } \\
\text { measurements } \\
\text { (microscope) }\end{array}$ \\
\hline Chan et al., 2018 & China & 7 & Cadavers & 17 & $3.7 \times 13 \mathrm{~mm}$ & $\begin{array}{c}\text { CBCT (3D } \\
\text { Accuitomo 170), } \\
\text { US }\end{array}$ & $\begin{array}{l}\text { CBCT: } 120 \mathrm{kV}, \\
18.66 \mathrm{~mA}, 20 \mathrm{~s}, 80 \\
\mu \mathrm{m} ; \mathrm{US}: 25 \mathrm{MHz}\end{array}$ & $\begin{array}{c}\text { Direct } \\
\text { measurements } \\
\text { (caliper) }\end{array}$ \\
\hline Degen et al., 2016 & Germany & 10 & $\begin{array}{l}\text { Bovine } \\
\text { ribs }\end{array}$ & 10 & $3.8 \times 11 \mathrm{~mm}$ & $\begin{array}{l}\text { CBCT (Galileos, } \\
\text { Sirona), US }\end{array}$ & $\begin{array}{l}85 \mathrm{kV}, 10 \mathrm{~mA}, 30 \mathrm{~s} ; \\
\text { US: } 42 \mathrm{MHz} \\
\text { bandwidth } 95 \%\end{array}$ & $\begin{array}{c}\text { Direct } \\
\text { measurements } \\
\text { (microscope) }\end{array}$ \\
\hline $\begin{array}{c}\text { Gonzáles-Martín et } \\
\text { al., } 2015\end{array}$ & USA & 10 & $\begin{array}{l}\text { Bovine } \\
\text { ribs }\end{array}$ & 20 & - & $\begin{array}{l}\text { CT (Brightspeed); } \\
\text { CBCT (iCAT, } \\
\text { NewTom) }\end{array}$ & \begin{tabular}{|c|} 
CT: $120 \mathrm{kV}, 60 \mathrm{~mA}, 4 \mathrm{~s}$ \\
$625 \mu \mathrm{m} ;$ iCAT: \\
$110 \mathrm{kV}, 4.8 \mathrm{~s}$ \\
$2-3.2 \mathrm{~mA}, 300 \mu \mathrm{m} ;$ \\
NewTom: $110 \mathrm{kV}$ \\
$4 \mathrm{~mA}, 5,4 \mathrm{~s}, 200 \mu \mathrm{m}$
\end{tabular} & $\begin{array}{c}\text { Direct } \\
\text { measurements } \\
\text { (caliper) }\end{array}$ \\
\hline Liedke et al., 2018 & Brazil & 40 & $\begin{array}{c}\text { Dry } \\
\text { porcine } \\
\text { mandible }\end{array}$ & 3 & $4 \times 9 \mathrm{~mm}$ & CBCT (Scanora) & $\begin{array}{c}\text { 1) } 90 \mathrm{kVp}, 6.3 \mathrm{~mA} \\
13 \mathrm{~s}, 200 \mu \mathrm{m} ; 2) 90 \\
\mathrm{kVp}, 6.3 \mathrm{~mA}, 20 \mathrm{~s} \\
130 \mu \mathrm{m} ;\end{array}$ & $\begin{array}{c}\text { Digital } \\
\text { photograph }\end{array}$ \\
\hline Marotti et al., 2019 & Germany & 8 & $\begin{array}{l}\text { Porcine } \\
\text { ribs }\end{array}$ & 8 & $3.8 \times 11 \mathrm{~mm}$ & $\begin{array}{l}\text { CBCT (Galileos, } \\
\text { Sirona); US }\end{array}$ & \begin{tabular}{|c|} 
CBCT: $85 \mathrm{kV}, 10 \mathrm{ma}$, \\
30S, $300 \mu \mathrm{m}$; US: \\
$75 \mathrm{MHz}$, aperture \\
$6.35 \mathrm{~mm}$, focus 2 \\
\end{tabular} & Optical scanner \\
\hline Rásko et al., 2016 & Hungary & 1 & $\begin{array}{c}\text { Porcine } \\
\text { mandible }\end{array}$ & 3 & $\begin{array}{c}4.3 \times 11 \mathrm{~mm} ; \\
3.8 \times 11 \mathrm{~mm} ; 3.8 \times 13 \mathrm{~mm}\end{array}$ & CBCT (iCAT) & $\begin{array}{c}120 \mathrm{kV}, 18 \mathrm{~mA}, 8,9 \mathrm{~s}, \\
200 \mu \mathrm{m},\end{array}$ & $\begin{array}{l}\text { CBCT without } \\
\text { implants }\end{array}$ \\
\hline Razavi et al., 2010 & $\begin{array}{l}\text { United } \\
\text { Kingdom }\end{array}$ & 10 & $\begin{array}{l}\text { Bovine } \\
\text { ribs }\end{array}$ & 10 & $4 \times 11 \mathrm{~mm}$ & $\begin{array}{l}\text { CBCT (i-CAT } \\
\text { NG and } \\
\text { Accuitomo 3D, } \\
\text { Morita) }\end{array}$ & $\begin{array}{c}\text { i-CAT: } 120 \mathrm{kV}, \\
18.54 \mathrm{~mA}, 0.3 \mathrm{~mm} \\
\text { voxel size; } \\
\text { Accuitomo: } 80 \mathrm{kV}, \\
4 \mathrm{~mA}, 125 \mu \mathrm{m} \text { voxel } \\
\text { size } \\
\end{array}$ & $\begin{array}{c}\text { Direct } \\
\text { measurements } \\
\text { (microscope) }\end{array}$ \\
\hline Ritter et al., 2014 & Germany & 12 & Dogs & 26 & - & $\begin{array}{c}\text { CBCT (Galileos, } \\
\text { Sirona) }\end{array}$ & $\begin{array}{c}\text { CBCT: } 85 \mathrm{kV}, 28 \mathrm{~mA}, \\
300 \mu \mathrm{m} \text { voxel size }\end{array}$ & $\begin{array}{c}\text { Direct } \\
\text { measurements } \\
\text { (Histology) }\end{array}$ \\
\hline $\begin{array}{c}\text { Sheridan et al., } \\
2018\end{array}$ & USA & 9 & Cadavers & 19 & $\begin{array}{l}4 \times 10 \mathrm{~mm} \\
4 \times 12 \mathrm{~mm}\end{array}$ & $\begin{array}{c}\text { CBCT (3D } \\
\text { Accuitomo 170) }\end{array}$ & $\begin{array}{c}120 \mathrm{kV}, 18.66 \mathrm{~mA}, \\
20 \mathrm{~s}, 400 \mu \mathrm{m} ;\end{array}$ & $\begin{array}{l}\text { CBCT without } \\
\text { implants }\end{array}$ \\
\hline
\end{tabular}




\begin{tabular}{|c|c|c|c|c|c|c|c|c|}
\hline \multicolumn{2}{|l|}{ Study } & \multicolumn{2}{|c|}{ Sample } & \multirow{2}{*}{\begin{tabular}{|c|}
- \\
$\underset{\text { Implants }}{\text { (n) }}$
\end{tabular}} & \multirow{2}{*}{$\begin{array}{c}- \\
\text { Implant Dimension } \\
\text { (diameter } x \text { height) }\end{array}$} & \multicolumn{3}{|c|}{ Bone Assessment } \\
\hline Author Year & Country & $\begin{array}{c}\text { Bone } \\
\text { Sample } \\
\text { (n) }\end{array}$ & Type & & & $\begin{array}{c}\text { Imaging } \\
\text { Technique }\end{array}$ & $\begin{array}{c}\text { Exposure } \\
\text { Parameters }\end{array}$ & Gold Standard \\
\hline $\begin{array}{c}\text { Shiratori et al., } \\
2012\end{array}$ & Brazil & 8 & Skulls & 31 & $3.75 \times 13 \mathrm{~mm}$ & CBCT (i-CAT) & $\begin{array}{l}120 \mathrm{kV}, 46.72 \mathrm{~mA}, \\
40 \mathrm{~s}, 250 \mu \mathrm{m} \text { voxel } \\
\text { size }\end{array}$ & $\begin{array}{c}\text { Direct } \\
\text { measurements } \\
\text { (microscope) }\end{array}$ \\
\hline $\begin{array}{c}\text { Vanderstuyft et al., } \\
2019\end{array}$ & Belgium & 5 & Cadavers & 44 & $3.6 \times 13 \mathrm{~mm}$ & $\begin{array}{c}\text { CBCT (1: } \\
\text { NewTom, } \\
\text { Verona; } 2: \\
\text { Accuitomo 170, } \\
\text { Morita) }\end{array}$ & $\begin{array}{l}\text { NewTom: } 110 \mathrm{kVp} \text {, } \\
5.2 \mathrm{~mA}, 150 \mu \mathrm{m} \\
\text { Accuitomo: } 90 \mathrm{kVp} \\
5 \mathrm{~mA}, 160 \mu \mathrm{m}\end{array}$ & $\begin{array}{l}\text { CBCT without } \\
\text { implants }\end{array}$ \\
\hline
\end{tabular}

Table 2. Summary of outcomes of included articles. $\mathrm{CBCT}=$ cone beam computed tomography; $\mathrm{CT}=$ computed tomography; US $=$ ultrasound .

\begin{tabular}{|c|c|c|c|c|c|}
\hline \multirow{2}{*}{ Author, year } & \multicolumn{3}{|c|}{ Measurements } & \multirow{2}{*}{ Findings } & \multirow{2}{*}{ Conclusion } \\
\hline & Points & Examiner & Repeteability & & \\
\hline Bohner et al., 2017 & $\begin{array}{c}\text { Dental implant to bone surface } \\
\text { at apical and } 5 \mathrm{~mm} \text { above }\end{array}$ & 1 & 3 & $\begin{array}{c}\text { No difference between CBCT and } \\
\text { physical measurements }\end{array}$ & CBCT is accurate \\
\hline Bohner et al., 2019 & $\begin{array}{c}\text { Dental implant to bone surface } \\
\text { at apical and } 5 \mathrm{~mm} \text { above }\end{array}$ & 1 & 3 & $\begin{array}{l}\text { No difference between CBCT and } \\
\text { US to the control group }\end{array}$ & $\begin{array}{c}\text { Trueness of US was similar } \\
\text { to the one of CBCT }\end{array}$ \\
\hline Chan et al., 2018 & $\begin{array}{l}\text { Outsurface of bone crest and } \\
\text { implant surface } 1 \mathrm{~mm} \text { from the } \\
\text { bone crest }\end{array}$ & 1 & 1 & $\begin{array}{l}\text { The mean absolute difference } \\
\text { among groups ranged } \\
\text { from } 0.033 \text { to } 0.24 \mathrm{~mm} .\end{array}$ & $\begin{array}{l}\text { Ultrasound can accurately } \\
\text { measure bone dimensions }\end{array}$ \\
\hline Degen et al., 2016 & $\begin{array}{l}\text { Distance between dental } \\
\text { implant and bone surface }\end{array}$ & 1 & 1 & $\begin{array}{c}\text { Median deviation was higher for } \\
\text { ultrasound (US) }(0.23 \mathrm{~mm}) \\
\text { compared to CBCT measurements } \\
(0.19 \mathrm{~mm})\end{array}$ & $\begin{array}{l}\text { US showed a high potential } \\
\text { for bone evaluation }\end{array}$ \\
\hline $\begin{array}{c}\text { Gonzáles-Martín et al., } \\
2015\end{array}$ & $1 \mathrm{~mm}$ apical to the bone crest & 2 & 1 & CBCT underestimated buccal bone & $\begin{array}{c}\text { Devices presented low } \\
\text { accuracy to measure bone }\end{array}$ \\
\hline Liedke et al., 2018 & $\begin{array}{c}\text { Distance between bone and } \\
\text { implant surface from occlusal } \\
\text { view }\end{array}$ & 3 & 1 & $\begin{array}{l}\text { Low resolution jeopardize bone } \\
\text { detection }\end{array}$ & $\begin{array}{l}\text { CBCT overestimated bone } \\
\text { thickness }\end{array}$ \\
\hline Marotti et al., 2019 & $\begin{array}{c}\text { Distance between implant and } \\
\text { bone surface along the long } \\
\text { axis of the implant }\end{array}$ & 2 & 1 & $\begin{array}{l}\text { US and CBCT showed similar } \\
\text { measurement values to optical } \\
\text { scanner }\end{array}$ & $\begin{array}{l}\text { US presented a higher } \\
\text { accuracy in comparison to } \\
\text { CBCT }\end{array}$ \\
\hline Rásko et al., 2016 & $\begin{array}{c}\text { Measurements were made at } \\
\text { each thickness level }\end{array}$ & 1 & 1 & $\begin{array}{l}\text { Deviation increased with a reduced } \\
\text { bone thickness }\end{array}$ & $\begin{array}{l}\text { CBCT was not accurate, } \\
\text { especially for thin bone }\end{array}$ \\
\hline Razavi et al., 2010 & $\begin{array}{l}\text { Distance between dental } \\
\text { implant and bone surface at } \\
\text { implant threads } 3,6 \text { and } 9 \mathrm{~mm} \\
\text { from the top of the implant }\end{array}$ & 10 & 2 & $\begin{array}{l}\text { Bone thickness calculation showed } \\
\text { a mean deviation of } 0.14 \pm 0.15 \mathrm{~mm} \\
\text { for Accuitomo and } 0.46 \pm 0.24 \mathrm{~mm} \\
\text { for I-CAT. For bone level, the } \\
\text { mean deviation was } 0.76 \pm 0.57 \mathrm{~mm} \\
\text { to Accuitomo and } 2.10 \pm 1.58 \mathrm{~mm} \text { to } \\
\text { I-CAT }\end{array}$ & $\begin{array}{l}\text { i-CAT did not produce } \\
\text { sufficient resolution for the } \\
\text { thin bone }\end{array}$ \\
\hline Ritter et al., 2014 & $\begin{array}{c}\text { From dental implant middle to } \\
\text { bone surface, } 4 \mathrm{~mm} \text { above } \\
\text { apical of implant. }\end{array}$ & 2 & 2 & $\begin{array}{c}\text { Mean deviation ranged from } 0.06 \text { to } \\
2.61 \mathrm{~mm} \text { to CBCT and } 0.12 \text { to } 0.43 \\
\text { to IR }\end{array}$ & $\begin{array}{l}\text { CBCT provided usable } \\
\text { information about bone } \\
\text { dimension }\end{array}$ \\
\hline Sheridan et al., 2018 & $\begin{array}{l}\text { At the implant } \\
\text { platform and apex }\end{array}$ & - & 1 & $\begin{array}{c}\text { No statistical difference was found } \\
\text { in images with and without } \\
\text { implants }\end{array}$ & $\begin{array}{c}\text { Dental implants to not } \\
\text { hamper the measurements } \\
\text { of bone thickness by CBCT }\end{array}$ \\
\hline Shiratori et al., 2012 & $\begin{array}{l}\text { Dental implant to bone surface } \\
\text { at apical and } 5 \mathrm{~mm} \text { above }\end{array}$ & 1 & 3 & $\begin{array}{l}\text { Mean difference for CBCT was } \\
0.04 \pm 0.01 \mathrm{~mm} \text { for bone thickness } \\
\text { and } 0.13 \pm 0.86 \mathrm{~mm} \text { for bone level }\end{array}$ & $\mathrm{CBCT}$ is accurate \\
\hline $\begin{array}{c}\text { Vanderstuyft et al., } \\
2019\end{array}$ & $\begin{array}{l}2,4, \text { and } 6 \mathrm{~mm} \text { to the implant } \\
\text { shoulder }\end{array}$ & 1 & 1 & $\begin{array}{l}\text { Bone thickness was underestimated } \\
\text { by } 0.3 \mathrm{~mm}\end{array}$ & $\begin{array}{l}\text { CBCT underestimated bone } \\
\text { thickness }\end{array}$ \\
\hline
\end{tabular}




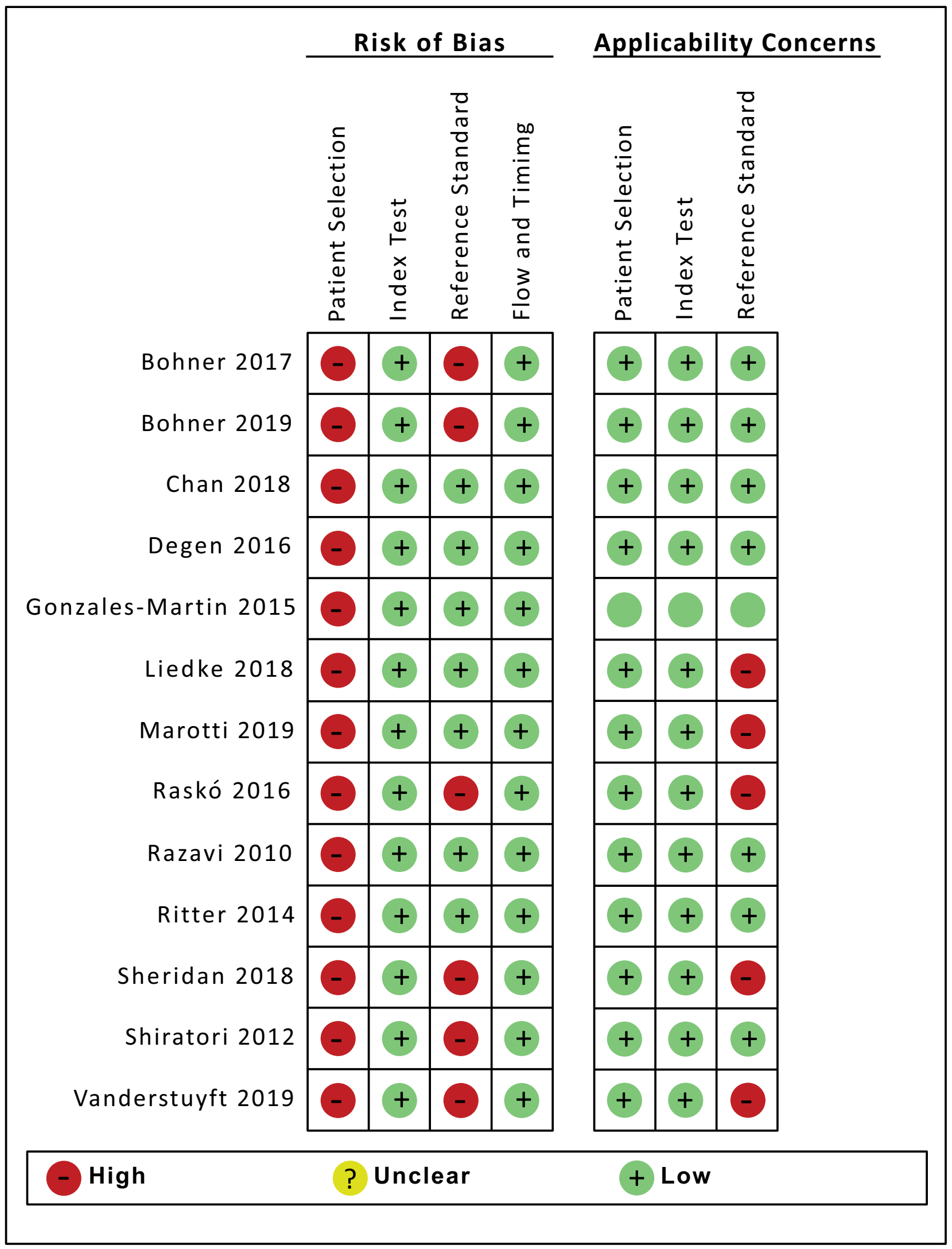

Fig. (2). Risk of bias within studies with QUADAS-2. 
With regard to the test group, all studies presented a low risk of bias. It was unclear whether the reference standard was interpreted without knowledge of the index result. However, this was not considered a risk due to the limitations ofthe invitro study design.

Measurements of bone thickness, which were not performed on the physical bone samples, but cast models instead, were considered high risk. Furthermore, the studies that used digital images as gold standards were considered doubtfulforanswering the focused question of this review.

\subsection{Results of Individual Studies}

All studies evaluated the accuracy of CBCT with reference to standard values. In comparison with histological samples, Ritter et al. (2014) [12] showed a measurement error of $0.42 \mathrm{~mm}$ for buccal bone thickness measured by CBCT. According to Degen et al. (2016) [27], CBCT showed a deviation of $18 \%$ when measurements were performed in the middle or center of the implant. Nonetheless, Razavi et al. (2010) [34] showed that measurement error ranged from $23 \%$ to $86 \%$ with different CBCT devices.

Shiratori et al. (2012) [32] showed an underestimation of up to $0.07 \mathrm{~mm}$, whereas Gonzales-Martín et al. (2015) [26]found that the measurement was underestimated in a range from $0.3 \mathrm{~mm}$ to $0.5 \mathrm{~mm}$. No significant difference was found when comparing conventional with cone-beam computed tomography. The highest values were found by Bohner et al. $(2017 ; 2019)$ [29, 33], who showed a deviation of $0.78 \mathrm{~mm}$ for measurements at the apex and $0.40 \mathrm{~mm}$ for measurements $5 \mathrm{~mm}$ abovethe apex.

When considering preoperative CBCT images, Raskó et al. (2016) [35] showed that bone thickness measurements ranged from $0.26 \mathrm{~mm}$ to $1.65 \mathrm{~mm}$ when $\mathrm{CBCT}$ images were taken without implants, and from $0 \mathrm{~mm}$ to $1.46 \mathrm{~mm}$ in CBCT images taken after implantation. Sheridan et al. (2018) [31] showed an underestimation of $0.04 \mathrm{~mm}$ when measurements were taken at the implant platform and of $0.02 \mathrm{~mm}$ when these were taken at the implant apex after placement of implants. Likewise, Vanderstuyft et al. (2019) [37] found a mean bone thickness deviation of up to $0.27 \mathrm{~mm}$ when compared with CBCT images without implants. In comparison with optical imaging, Marotti et al. (2019) [30] showed a mean measurement error of $0.2 \mathrm{~mm}$ for CBCT. This mean was in agreement with the study of Liedke et al. (2019) [36], ' who showed that most measurement errors were under $0.5 \mathrm{~mm}$ in comparison with measurements taken in digital photographs.

Ultrasound-based techniques were evaluated in four studies. Degen et al. (2016) [27] showed a mean error of 12.1\% in comparison withthe gold standard. In comparison with optical images, the measurement error was $0.28 \mathrm{~mm}$. [30] Chan et al. (2018) [28] showed a mean difference of $0.3 \mathrm{~mm}$ in comparison with direct measurements. Likewise, Bohner et al. (2019) [29] described a mean difference of $0.38 \mathrm{~mm}$ when scanning with high-resolution ultrasound.

\subsection{Synthesis of Results}

$\mathrm{I}^{2}$ among studies was $11 \% \quad(\mathrm{p}=0.34)$. There was nostatisticallysignificant difference between the CBCT and the gold standard $(\mathrm{p}=0.81)$. Fig. (3) shows the mean values and standard deviation of the peri-implant buccal bone thickness measured by $\mathrm{CBCT}$ and by the Gold Standard.The mean difference between measurements of bone thickness between them was $-0.0 .3 \mathrm{~mm}$ [ $95 \% \mathrm{CI}-0.29 ; 0.253 \mathrm{~mm}]$.

\subsection{Risk of Bias Across Studies}

The diversified methodology was considered a bias across studies.

\section{DISCUSSION}

The estimation of buccal bone thickness is an important parameter to predict the outcome of dental implant treatment. To date, the most reliable alternative to provide a non-invasive assessment of the buccal bone of the jawbone is CBCT. Nonetheless, novel imaging techniques have been investigated to overcome the limitations of a tomographic technique, such as ionizing radiation and artifacts. This research aimed to search the literature relative to the question about whether currently available techniques can provide accurate measurements of buccal bone during implant assessment.

According to the included studies, CBCT deviates from real measurements by less than $1 \mathrm{~mm}$, which is considered

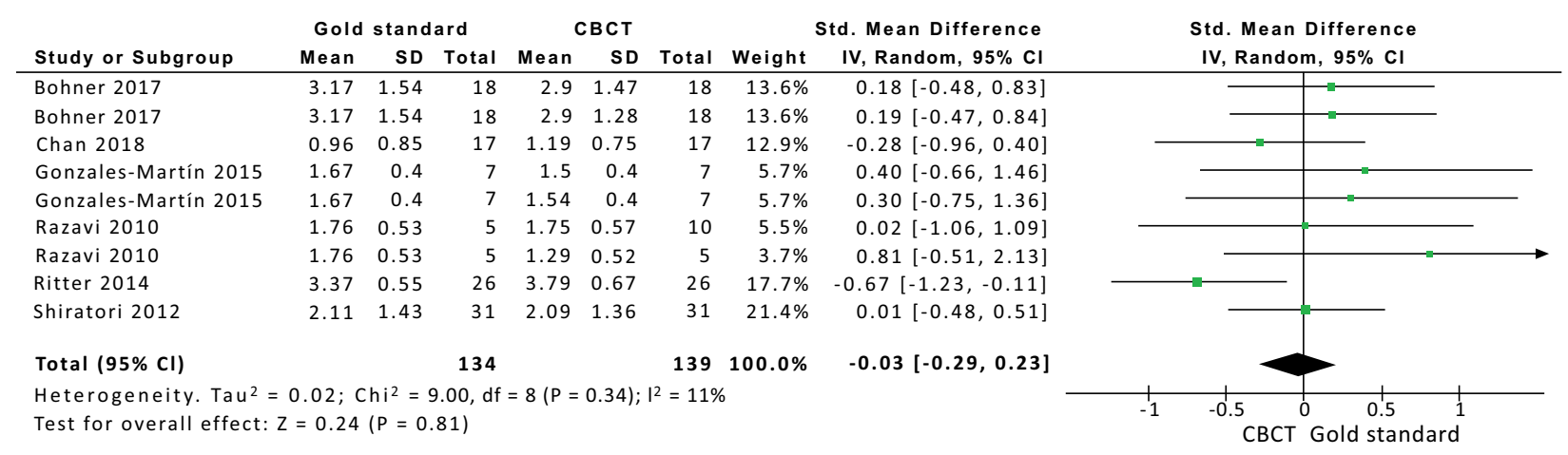

Fig. (3). Forest plot evaluating bone thickness determined by CBCT. 
acceptable from a clinical point of view. Nonetheless, this accuracy seems to decrease as the bone becomes thinner. In this sense, Gonzales-Martín et al. (2015) [26] showed that in up to $63 \%$ of the cases, the buccal bone was not visible in CBCT imageswhen the thickness was lower than $1 \mathrm{~mm}$. This statement is in agreement with the findings of Shiratori et al. (2012) [32], who attributed the mean deviation range of $-0.02 \mathrm{~mm}$ to $0.07 \mathrm{~mm}$ to the bone volume variation. Accordingly, Razavi et al. (2010) [34] claimed that an underestimation of bone thickness occurred when this was thinner than $0.8 \mathrm{~mm}$.

The inaccuracy of CBCT assessment is related to the appearance of metal artifacts, which may hamper the visualization of bone-implant contact [38]. Furthermore, exposure parameters and partial effect may affect the image accuracy [14]. In this sense, better accuracy is provided when the image resolution is increased by using a lower voxel size $[28,31]$

With regard to ultrasound-based techniques, these provide real-time images without involving radiation, which may be considered an advantage of the technique for periodical assessment of peri-implant bone. Out of the included studies, 4 of them used a high-frequency US-transducer to scan hard tissue. Although studies reported that US can measure bone dimensions with an accuracy similar to CBCT, this is a sensitive technique, which can lead to distortions of the final image [18, 30, 39]. Thus, further studies are required to improve its use during clinical practice.

The included studies assessed only dental implants fully covered by bone. An important limitation of this study was that it did not take intoconsideration the presence of dehiscence or fenestrations, which could affect the results. Furthermore, the results described in this review are limited to in-vitro studies. The lack of clinical studies relative to this issue is possibly related to the need for a high number of cases to provide statistically significant results. Thus, there is a limitation to conducting this type of study design in agreement with the ALARA principle [16]. However, in a clinical situation, factors related to patient movements could also affect image resolution.

This review aimed to help clinicians to understand the advantages and limitations of the imaging methods currently available for the assessment of peri-implant bone. However, it must be emphasized that the choice of imaging technique dependson the patient's need, professional preference and the additional benefits provided by the examination. Factors such as radiation dose, costs and individual needs must be taken into considerationin future researches [40].

\section{CONCLUSION}

- $\quad$ CBCT showed an acceptable accuracy for assessing peri-implant buccal bone thickness.

- US showed an accuracy similar to that ofCBCT in all evaluated studies.

- Due to the lack of studies in the literature, no conclusion could be drawn with respect to other techniques.

\section{CONSENT FOR PUBLICATION}

Not applicable.

\section{STANDARD FOR REPORTING}

PRISMA guidelines and methodology were followed.

\section{FUNDING}

None.

\section{CONFLICT OF INTEREST}

The authors declare no conflict of interest, financial or otherwise.

\section{ACKNOWLEDGEMENTS}

Declared none.

\section{Appendix 1. Excluded articles and reason.}

\begin{tabular}{|c|c|}
\hline Author, Year & Exclusion criteria \\
\hline Azevedo-Vaz et al 2013 & 3 \\
\hline Azevedo-Vaz et al 2013b & 3 \\
\hline Azevedo-Vaz et al 2013c & 3 \\
\hline Azevedo-Vaz et al 2016 & 3 \\
\hline Becker et al 2015 & 2 \\
\hline Benic et al 2012 & 4 \\
\hline Borg et al 2000 & 3 \\
\hline Bousquet et al 2007 & 2 \\
\hline Bousquet et al 2008 & 2 \\
\hline Bridcut et al 2001 & 2 \\
\hline Choi et al 2012 & 3 \\
\hline Dave et al 2012 & 3 \\
\hline Draenert et al 2007 & 2 \\
\hline Duttenhoefer et al 2015 & 2 \\
\hline Fienitz et al 2011 & 3 \\
\hline
\end{tabular}




\begin{tabular}{|c|c|}
\hline Author, Year & Exclusion criteria \\
\hline Fourmousis et al 1994 & 2 \\
\hline Gher et al 1995 & 3 \\
\hline Garcia-Garcia et al 2016 & 3 \\
\hline Golubovic et al 2012 & 3 \\
\hline Gonzales-Garcia et al 2013 & 2 \\
\hline Gonzáles-Martin et al 2016 & 3 \\
\hline Grondhal et al 1997 & 2 \\
\hline Kamburoglu et al 2014 & 3 \\
\hline Kavadella et al 2006 & 3 \\
\hline Kuhl et al 2015 & 3 \\
\hline King et al 2002 & 2 \\
\hline Linrachtamorn et al 2000 & 1 \\
\hline Ludlow et al 1995 & 2 \\
\hline Mangione et al 2013 & 2 \\
\hline Matsuda et al 2001 & 2 \\
\hline Meijer et al 1993 & 2 \\
\hline Meijer et al 1995 & 2 \\
\hline Mengel et al 2006 & 3 \\
\hline Merheb et al 2015 & 2 \\
\hline Miyamoto et al 2011 & 2 \\
\hline Ogusanglu et al 2012 & 2 \\
\hline Pasquet et al 2009 & 1 \\
\hline Pauwels et al 2014 & 2 \\
\hline Pinheiro et al 2015 & 3 \\
\hline Pinheiro 2015b & 3 \\
\hline Raes et al 2013 & 2 \\
\hline Rashedi et al 2003 & 2 \\
\hline Reddy et al 1994 & 2 \\
\hline Sanchez et al 2004 & 2 \\
\hline Schliephake et al 2013 & 3 \\
\hline Sennerby et al 2001 & 4 \\
\hline Sewerin et al 1997 & 3 \\
\hline Shokri et al 2015 & 2 \\
\hline Sirin et al 2012 & 3 \\
\hline Slak et al 2014 & 1 \\
\hline Sundén et al 1995 & 2 \\
\hline Svenson et al 1996 & 3 \\
\hline Van Oossterwyck, et al 2000 & 4 \\
\hline Vandeweghe et al 2013 & 4 \\
\hline Wang et al 2013 & 3 \\
\hline Wang et al 2013b & 1 \\
\hline Webber et al 1996 & 2 \\
\hline Zechner et al 2003 & 2 \\
\hline Dagassan-Berndt et al & 3 \\
\hline Tang et al & 3 \\
\hline Vidor et al & 3 \\
\hline Vidor et al & 3 \\
\hline Peterson et al & 3 \\
\hline Mercado et al & 3 \\
\hline Flügge et al & 3 \\
\hline Sheikhi et al & 3 \\
\hline Yen et al & 3 \\
\hline Chan et al & 3 \\
\hline Chan et al & 3 \\
\hline
\end{tabular}




\begin{tabular}{|c|c|}
\hline \multicolumn{1}{|c|}{ Author, Year } & Exclusion criteria \\
\hline Salmon et al & 3 \\
\hline 1. Case reports, reviews, letters, abstracts; 2 . Studies that did not compare the accuracy of imaging techniques with the gold-standard (histology or direct measurements); 3.
\end{tabular}

1. Case reports, reviews, letters, abstracts; 2 . Studies that did not compare the accuracy of imaging techniques with the gold-standard (histology or direct measurements); 3 . Studies that did not evaluate the bone dimension or did not present data enough to calculate them; 4 . Studies that evaluated methods not reliable for clinical use.

\section{REFERENCES}

[1] Jung RE, Zembic A, Pjetursson BE, Zwahlen M, Thoma DS. Systematic review of the survival rate and the incidence of biological, technical, and aesthetic complications of single crowns on implants reported in longitudinal studies with a mean follow-up of 5 years. Clin Oral Implants Res 2012; 23(Suppl. 6): 2-21.

[http://dx.doi.org/10.1111/j.1600-0501.2012.02547.x] [PMID: 23062124]

[2] Slagter KW, Meijer HJ, Bakker NA, Vissink A, Raghoebar GM. Immediate single-tooth implant placement in bony defects in the esthetic zone: A 1-year randomized controlled trial. J Periodontol 2016; 87(6): 619-29.

[http://dx.doi.org/10.1902/jop.2016.150417] [PMID: 26876349]

[3] Buser D, Bornstein MM, Weber HP, Grütter L, Schmid B, Belser UC. Early implant placement with simultaneous guided bone regeneration following single-tooth extraction in the esthetic zone: a crosssectional, retrospective study in 45 subjects with a 2- to 4-year followup. J Periodontol 2008; 79(9): 1773-81. [http://dx.doi.org/10.1902/jop.2008.080071] [PMID: 18771381]

[4] Buser D, Halbritter S, Hart C, et al. Early implant placement with simultaneous guided bone regeneration following single-tooth extraction in the esthetic zone: 12 -month results of a prospective study with 20 consecutive patients. J Periodontol 2009; 80(1): 152-62. [http://dx.doi.org/10.1902/jop.2009.080360] [PMID: 19228101]

[5] Merheb J, Van Assche N, Coucke W, Jacobs R, Naert I, Quirynen M. Relationship between cortical bone thickness or computerized tomography-derived bone density values and implant stability. Clin Oral Implants Res 2010; 21(6): 612-7.

[http://dx.doi.org/10.1111/j.1600-0501.2009.01880.x] [PMID: 20666788]

[6] Buser D, Chappuis V, Bornstein MM, Wittneben JG, Frei M, Belser UC. Long-term stability of contour augmentation with early implant placement following single tooth extraction in the esthetic zone: a prospective, cross-sectional study in 41 patients with a 5- to 9-year follow-up. J Periodontol 2013; 84(11): 1517-27.

[http://dx.doi.org/10.1902/jop.2013.120635] [PMID: 23347346]

[7] Hsu JT, Fuh LJ, Tu MG, Li YF, Chen KT, Huang HL. The effects of cortical bone thickness and trabecular bone strength on noninvasive measures of the implant primary stability using synthetic bone models. Clin Implant Dent Relat Res 2013; 15(2): 251-61

[http://dx.doi.org/10.1111/j.1708-8208.2011.00349.x]

[PMID: 21599830]

[8] Demircan S, Demircan E. Dental Cone Beam Computed Tomography Analyses of the Anterior Maxillary Bone Thickness for Immediate Implant Placement. Implant Dent 2015; 24(6): 664-8. [http://dx.doi.org/10.1097/ID.0000000000000340] [PMID: 26460741]

[9] Benic GI, Mokti M, Chen CJ, Weber HP, Hämmerle CH, Gallucci GO. Dimensions of buccal bone and mucosa at immediately placed implants after 7 years: a clinical and cone beam computed tomography study. Clin Oral Implants Res 2012; 23(5): 560-6.

[http://dx.doi.org/10.1111/j.1600-0501.2011.02253.x] [PMID: 22093013]

[10] Tey VH, Phillips R, Tan K. Five-year retrospective study on success, survival and incidence of complications of single crowns supported by dental implants. Clin Oral Implants Res 2016. [PMID: 27334865]

[11] Chappuis V, Araújo MG, Buser D. Clinical relevance of dimensional bone and soft tissue alterations post-extraction in esthetic sites. Periodontol 2000 2017; 73(1): 73-83.

[http://dx.doi.org/10.1111/prd.12167] [PMID: 28000281]

[12] Ritter L, Elger MC, Rothamel D, et al. Accuracy of peri-implant bone evaluation using cone beam $\mathrm{CT}$, digital intra-oral radiographs and histology. Dentomaxillofac Radiol 2014; 43(6)20130088 [http://dx.doi.org/10.1259/dmfr.20130088] [PMID: 24786136]

[13] Chappuis V, Bornstein MM, Buser D, Belser U. Influence of implant neck design on facial bone crest dimensions in the esthetic zone analyzed by cone beam CT: a comparative study with a 5-to-9-year follow-up. Clin Oral Implants Res 2015. [PMID: 26370904]

[14] Scarfe WC, Farman AG. What is cone-beam CT and how does it work? Dent Clin North Am 2008; 52(4): 707-730, v. [http://dx.doi.org/10.1016/j.cden.2008.05.005] [PMID: 18805225]

[15] Behnia H, Motamedian SR, Kiani MT, Morad G, Khojasteh A. Accuracy and reliability of cone beam computed tomographic measurements of the bone labial and palatal to the maxillary anterior teeth. Int J Oral Maxillofac Implants 2015; 30(6): 1249-55. [http://dx.doi.org/10.11607/jomi.3856] [PMID: 26478968]

[16] Hendee WR, Edwards FM. ALARA and an integrated approach to radiation protection. Semin Nucl Med 1986; 16(2): 142-50. [http://dx.doi.org/10.1016/S0001-2998(86)80027-7] [PMID: 3961515]

[17] Bornstein MM, Scarfe WC, Vaughn VM, Jacobs R. Cone beam computed tomography in implant dentistry: a systematic review focusing on guidelines, indications, and radiation dose risks. Int J Oral Maxillofac Implants 2014; 29(Suppl.): 55-77.

[http://dx.doi.org/10.11607/jomi.2014suppl.g1.4] [PMID: 24660190]

[18] Salmon B, Le Denmat D. Intraoral ultrasonography: development of a specific high-frequency probe and clinical pilot study. Clin Oral Investig 2012; 16(2): 643-9.

[http://dx.doi.org/10.1007/s00784-011-0533-z] [PMID: 21380502]

[19] Duttenhoefer F, Mertens ME, Vizkelety J, Gremse F, Stadelmann VA, Sauerbier S. Magnetic resonance imaging in zirconia-based dental implantology. Clin Oral Implants Res 2015; 26(10): 1195-202.

[http://dx.doi.org/10.1111/clr.12430] [PMID: 24893967]

[20] Wanner L, Ludwig U, Hövener JB, Nelson K, Flügge T. Magnetic resonance imaging-a diagnostic tool for postoperative evaluation of dental implants: a case report. Oral Surg Oral Med Oral Pathol Oral Radiol 2018; 125(4): e103-7.

[http://dx.doi.org/10.1016/j.oooo.2018.01.005] [PMID: 29501353]

[21] Benic GI, Elmasry M, Hämmerle $\mathrm{CH}$. Novel digital imaging techniques to assess the outcome in oral rehabilitation with dental implants: a narrative review. Clin Oral Implants Res 2015; 26(Suppl. 11): $86-96$.

[http://dx.doi.org/10.1111/clr.12616] [PMID: 26010421]

[22] Tahmaseb A, Wismeijer D, Coucke W, Derksen W. Computer technology applications in surgical implant dentistry: a systematic review. Int J Oral Maxillofac Implants 2014; 29(Suppl.): 25-42. [http://dx.doi.org/10.11607/jomi.2014suppl.g1.2] [PMID: 24660188]

[23] Liberati A, Altman DG, Tetzlaff J, et al. The PRISMA statement for reporting systematic reviews and meta-analyses of studies that evaluate health care interventions: explanation and elaboration. J Clin Epidemiol 2009; 62(10): e1-e34.

[http://dx.doi.org/10.1016/j.jclinepi.2009.06.006] [PMID: 19631507]

[24] Whiting PF, Rutjes AW, Westwood ME, et al. QUADAS-2 Group. QUADAS-2: a revised tool for the quality assessment of diagnostic accuracy studies. Ann Intern Med 2011; 155(8): 529-36.

[http://dx.doi.org/10.7326/0003-4819-155-8-201110180-00009] [PMID: 22007046]

[25] Deeks JJBPGC. Cochrane Handbook for Systematic Reviews of Diagnostic Test Accuracy Version 09. The Cochrane Collaboration 2013.

[26] González-Martín O, Oteo C, Ortega R, Alandez J, Sanz M, Veltri M. Evaluation of peri-implant buccal bone by computed tomography: an experimental study. Clin Oral Implants Res 2016; 27(8): 950-5. [http://dx.doi.org/10.1111/clr.12663] [PMID: 26178780]

[27] Degen K, Habor D, Radermacher K, et al. Assessment of cortical bone thickness using ultrasound. Clin Oral Implants Res 2017; 28(5): 520-8. [http://dx.doi.org/10.1111/clr.12829] [PMID: 27018152]

[28] Chan HL, Sinjab K, Li J, Chen Z, Wang HL, Kripfgans OD. Ultrasonography for noninvasive and real-time evaluation of periimplant tissue dimensions. J Clin Periodontol 2018; 45(8): 986-95. [http://dx.doi.org/10.1111/jcpe.12918] [PMID: 29757464]

[29] Bohner L, Habor D, Tortamano P, Radermacher K, Wolfart S, Marotti J. Assessment of Buccal Bone Surrounding Dental Implants Using a High-Frequency Ultrasound Scanner. Ultrasound Med Biol 2019; 45(6): 1427-34.

[http://dx.doi.org/10.1016/j.ultrasmedbio.2019.02.002] 30940417]

[30] Marotti J, Neuhaus S, Habor D, et al. High-frequency ultrasound for assessment of peri-implant bone thickness. J Clin Med 2019; 8(10): 8. [http://dx.doi.org/10.3390/jcm8101539] [PMID: 31557872]

[31] Sheridan RA, Chiang YC, Decker AM, Sutthiboonyapan P, Chan HL, 
Wang HL. The effect of implant-induced artifacts on interpreting adjacent bone structures on cone-beam computed tomography scans. Implant Dent 2018; 27(1): 10-4.

[http://dx.doi.org/10.1097/ID.0000000000000684] [PMID: 29095787]

[32] Shiratori LN, Marotti J, Yamanouchi J, Chilvarquer I, Contin I, Tortamano-Neto P. Measurement of buccal bone volume of dental implants by means of cone-beam computed tomography. Clin Oral Implants Res 2012; 23(7): 797-804.

[http://dx.doi.org/10.1111/j.1600-0501.2011.02207.x] [PMID: 21631591]

[33] Bohner LOL, Tortamano P, Marotti J. Accuracy of linear measurements around dental implants by means of cone beam computed tomography with different exposure parameters. Dentomaxillofac Radiol 2017; 46(5)20160377

[http://dx.doi.org/10.1259/dmfr.20160377] [PMID: 28267928]

[34] Razavi T, Palmer RM, Davies J, Wilson R, Palmer PJ. Accuracy of measuring the cortical bone thickness adjacent to dental implants using cone beam computed tomography. Clin Oral Implants Res 2010; 21(7): $718-25$

[http://dx.doi.org/10.1111/j.1600-0501.2009.01905.x] [PMID: 20636726]

[35] Raskó Z, Nagy L, Radnai M, Piffkó J, Baráth Z. Assessing the accuracy of cone-beam computerized tomography in measuring thinning oral and buccal bone. J Oral Implantol 2016; 42(3): 311-4. [http://dx.doi.org/10.1563/aaid-joi-D-15-00188] [PMID: 26645480]
[36] Liedke GS, Spin-Neto R, da Silveira HED, Schropp L, Stavropoulos A, Wenzel A. Accuracy of detecting and measuring buccal bone thickness adjacent to titanium dental implants-a cone beam computed tomography in vitro study. Oral Surg Oral Med Oral Pathol Oral Radiol 2018; 126(5): 432-8.

[http://dx.doi.org/10.1016/j.oooo.2018.06.004] [PMID: 30126809]

[37] Vanderstuyft T, Tarce M, Sanaan B, Jacobs R, de Faria Vasconcelos $\mathrm{K}$, Quirynen $\mathrm{M}$. Inaccuracy of buccal bone thickness estimation on cone-beam CT due to implant blooming: An ex-vivo study. J Clin Periodontol 2019; 46(11): 1134-43.

[http://dx.doi.org/10.1111/jcpe.13183] [PMID: 31446644]

[38] Degen K, Habor D, Radermacher K, Heger S, Kern JS, Wolfart S, et al. Assessment of cortical bone thickness using ultrasound. Clin Oral Implants Res 2016.

[PMID: 27018152]

[39] Choi M, Culjat MO, Singh RS, White SN. Ultrasound imagery for dental implant diagnosis and treatment planning in a porcine model. $\mathrm{J}$ Prosthet Dent 2012; 108(6): 344-53.

[http://dx.doi.org/10.1016/S0022-3913(12)60190-5]

[PMID: 23217466]

[40] Bornstein MM, Al Nawas B, Kuchler U, Tahmaseb A. Consensus statements and recommended clinical procedures regarding contemporary surgical and radiographic techniques in implant dentistry. Int J Oral Maxillofac Implants 2013. [PMID: 23951565]

(C) 2020 Bohner et al.

This is an open access article distributed under the terms of the Creative Commons Attribution 4.0 International Public License (CC-BY 4.0), a copy of which is available at: (https://creativecommons.org/licenses/by/4.0/legalcode). This license permits unrestricted use, distribution, and reproduction in any medium, provided the original author and source are credited. 